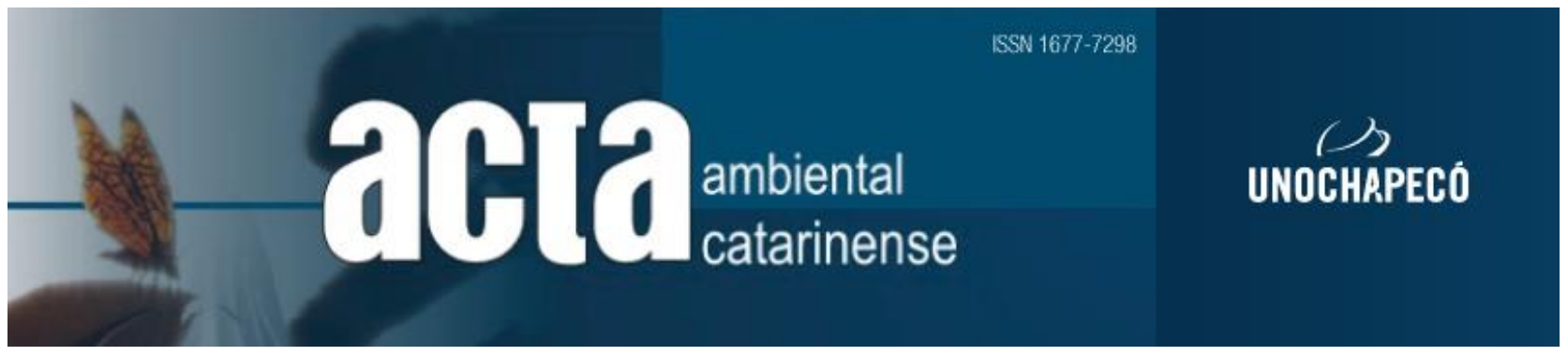

\title{
GESTÃO AMBIENTAL DE CEMITÉRIOS: UMA REVISÃO DA LITERATURA E SUGESTÃO DE PESQUISA
}

\author{
Jefferson Ferreira de Freitas Feitosa ${ }^{1}$ \\ Thalyta Isis Lira Campos² \\ Jéssica de Souza Bandeira ${ }^{3}$
}

${ }^{1}$ Mestrando no Programa de Pós-Graduação em Ciência Animal, Universidade Federal de Campina Grande - UFCG, Campus Patos

${ }^{2}$ Especializando no Programa de Pós-Graduação em Ecologia e Educação Ambiental, Universidade Federal de Campina Grande - UFCG, Campus Patos

${ }^{3}$ Especializando no Programa de Pós-Graduação em Ecologia e Educação Ambiental, Universidade Federal de Campina Grande - UFCG, Campus Patos

\section{Resumo}

O cemitério trata-se de um local apropriado para os atos de sepultamento e enterro de cadáveres; se uma pessoa falece doente, todas as bactérias, vírus e químicas ingeridas durante a sua vida eventualmente se misturam junto ao líquido derivado da decomposição; de forma que se for lixiviado e percolar, causa contaminação ao solo e mananciais gerando assim um risco de proliferação de doenças, se transformando numa questão de saúde pública. Diante disso, o artigo visa difundir pesquisas sobre a gestão de cemitérios no Brasil. No estudo ora apresentado, aborda o tema através de uma revisão da literatura por meio de artigos relacionados ao necrochorume, encontrados nas bases de dados do periódicos capes; afunilou-se a temática, circunscrevendo a análise dos textos que versam sobre a temática, aspectos e sugestão de pesquisas futuras na área.

Palavras-chave: Necrochorume, gestão ambiental, fitorremediação, água, solo

\begin{abstract}
The cemetery treats an appropriate place for burial and burial of corpses; if a person dies, all bacteria, viruses and chemicals are ingested during his life eventually mix with the liquid derived from the decomposition; so that if leached and percolate, it causes contamination to the soil and water sources, generating a risk of disease proliferation, becoming a public health issue. That said, the article aims to disseminate research on the management of cemeteries in Brazil. No study presented addresses the theme through a literature review through articles related to the necrochorume, found in the databases of periodic covers; after a theme, bypassing an analysis of the texts that deal with the theme, aspects and suggestions for future research in the area.
\end{abstract}

Keywords: Necrochorume, environmental management, phytoremediation, water, soil 


\section{INTRODUÇÃO}

Visando a necessidade do controle ambiental, empreendimentos como cemitérios tem recebido maior atenção no decorrer dos anos para a identificação das fontes poluidoras a fim de controlar seu potencial poluidor. As substâncias advindas desses locais oferecem grandes ameaças principalmente para os recursos hídricos, prejudicando sua disponibilidade para consumo.

A ineficiente gestão de resíduos é uma grande ameaça produzida pelos cemitérios, seja através das vestimentas que envolvem os corpos, até restos de caixões. Esses resíduos, geralmente, são depositados próximo as áreas de sepultamento e, ao entrar em contato com a água da chuva, podem fazer com que diversas substâncias se infiltrem no solo, podendo atingir as fontes hídricas (KEMERICH et al., 2012).

A decomposição dos corpos, caixões, vestimentas e substâncias introduzidas no corpo humano no decorrer da vida, gera o necrochorume (FIEDLER et al., 2012; JONKER e OLIVIER, 2012). O necrochorume é um líquido de elevado potencial poluidor que pode variar de região para região ou época de sepultamento devido aos diferentes costumes de cada indivíduo e localidade, sendo primordial considerar os diversos aspectos ambientais na escolha do local para a instalação de cemitérios.

Os problemas estruturais dos cemitérios podem ser considerados os principais agentes causadores da contaminação do solo e da água subterrânea com patógenos e metais pesados, em virtude de sua aplicação sem prévio estudo ambiental e da má conservação dos túmulos (KEMERICH et al., 2014).

Nos cemitérios, além da transferência de patologias para a população, os poluidores geram um desequilíbrio no ambiente, comprometendo o desenvolvimento de plantas por prejudicar a saúde do solo, águas subterrâneas e consequentemente também podendo atingir a fauna local, ocorrendo assim, sérios problemas de desequilíbrio ambiental.

Diante da relevância do tema acima exposto, esse estudo tem como objetivo apresentar e discutir achados na literatura referentes a gestão de cemitérios, compreendendo que esse setor tem um importante papel no âmbito ambiental.

\section{Material e Métodos}

A presente pesquisa estuda de forma qualitativa a literatura publicada em bases nacionais sobre gestão de cemitérios.

A pesquisa qualitativa tem natureza distinta e finalidade independente à pesquisa quantitativa, pois ela abrange aspectos que esta última não consegue englobar (SANTOS, CALÍOPE e BARROS NETO, 2017).

A pesquisa qualitativa é aquela que não utiliza modelos matemáticos ou estatísticos. É uma pesquisa interpretativa, onde o pesquisador se mantém em contato direto com o objeto de estudo (GUBA e LINCOLN, 2005; MARTINS e THEÓPHILO, 2007).

Quanto à natureza do estudo trata-se de uma pesquisa exploratória. De acordo com Gil (2017) a pesquisa exploratória é aquela que tem como objetivo uma maior familiaridade com o problema, para que o torne mais explícito e seja criada novas hipóteses. O objetivo principal da pesquisa exploratória é a melhoria de ideias.

Para a realização deste trabalho utilizou-se como método de pesquisa a revisão sistemática de literatura, com análise e discussão, sendo elaborado a partir de uma pesquisa através da plataforma de periódicos CAPES. A revisão da literatura é uma interpretação geral das pesquisas mais relevantes que utilizaram métodos explícitos e reproduzíveis. Nela deve estar claro os critérios para a inclusão quanto e exclusão dos artigos da base de dados escolhida (GREENHALGH, 1997). 
Foram incluídos na pesquisa os conteúdos publicados nos últimos anos, até março de 2020 nas principais revistas nacionais e internacionais de acordo com sua classificação Qualis da CAPES em A e B e algumas outras consideradas importantes para a área.

Os artigos selecionados foram analisados com o objetivo de fazer um histórico das publicações e o seu foco principal, como forma de traçar um panorama mais amplo sobre o uso desse referencial para estudos da gestão ambiental. Para tanto, utilizou a palavra "Necrochorume" como ponto de partida para a pesquisa.

\section{Resultados}

\subsection{ANÁLISE DOS TRABALHOS RELACIONADOS AO NECROCHORUME}

Somando-se todas as bases de dados, foram encontrados 34 artigos que citaram a palavra Necrochorume. Após a leitura dos títulos e resumo dos artigos percebeu-se que alguns artigos não desenvolvem nada a respeito da temática ou eram repetidos, então foram excluídos 3 , sendo selecionados 31 artigos que preenchiam os critérios inicialmente propostos. Percebeu-se que alguns artigos citam os termos geography, contaminação, cemitérios e copper como exemplo de pesquisas na área. Considerou-se então que este tipo de artigo também seria adequado à natureza da revisão bibliográfica aqui exigida, mesmo que parcialmente.

Na Tabela 1 encontra-se o número de artigos encontrados sobre o necrochorume nos periódicos observados.

Ao analisar os 31 artigos relacionados a gestão de cemitérios, tem-se como metodologia adotada na maior parte dos trabalhos a análise bacteriológica, microbiológica e físico-química, seguida de metais pesados. A contaminação dos aquíferos tem se tornado um dos problemas mais preocupantes nas questões de gestão dos recursos hídricos subterrâneos, visto que são considerados reservatórios estratégicos para a humanidade. Para contornar esse problema são adotadas, em várias partes do mundo, principalmente nos países mais desenvolvidos, medidas preventivas, pois uma vez contaminado, a recuperação do aquífero é extremamente difícil e onerosa (CUTRIM e CAMPOS, 2010).

Segundo Maia \& Cruz (2011) a vulnerabilidade intrínseca de um aquífero é decorrente das propriedades físico-químicas inerentes do meio aquífero que expressa a susceptibilidade hidrogeológica da água ser afetada por contaminantes. A metodologia GOD destina-se ao primeiro passo na avaliação do risco de poluição das águas subterrâneas, e destina-se, também, a priorizar, mas não substituir, ações sistemáticas de monitoramento e inspeção em campo (FOSTER, 1987).

O método GOD é um método simples e sistemático usado como abordagem exploratória para determinar o risco de contaminação das águas subterrâneas, sendo o acrônimo para três parâmetros atenuadores: $\mathrm{G}$ (confinamento hidráulico das águas subterrâneas) representa o confinamento hidráulico das águas subterrâneas no aqüífero e deve atribuir diferentes vulnerabilidades ao lençol freático, aqüíferos semi-confinados ou confinados; $\mathrm{O}$ (estratos subjacentes) descreve o tipo de materiais presentes na zona insaturada acima do aqüífero, de acordo com sua capacidade de neutralizar contaminantes; e D (Profundidade do lençol freático) mede a profundidade do nível do lençol freático, sendo uma proxy do tempo que os contaminantes necessitam para atingir o aqüífero. $\mathrm{Na}$ avaliação da vulnerabilidade de GOD, cada parâmetro de composição recebe um valor entre 0 e 1 , em que 0 representa vulnerabilidade mínima e 1 representa vulnerabilidade máxima. Por exemplo, o parâmetro $\mathrm{G}$ se aproximará de 1 se o aquífero não estiver confinado e diminuirá para 0 se o confinamento do aqüífero aumentar. 
Tabela 1. Resumo dos resultados da pesquisa até março de 2020

\begin{tabular}{|c|c|c|c|}
\hline Periódico & Pesquisa & Referência & Método de Pesquisa \\
\hline $\begin{array}{ll}\text { Revista } & \text { Águas } \\
\text { Subterrâneas } & \end{array}$ & $\begin{array}{l}\text { Qualidade das Águas } \\
\text { Subterrâneas em áreas } \\
\text { de Cemitérios }\end{array}$ & Migliorini et al. 2006 & $\begin{array}{l}\text { Análises } \\
\text { bacteriológicas, } \\
\text { físico-químicas } \\
\text { químicas }\end{array}$ \\
\hline Ciência e Natura & $\begin{array}{l}\text { Banco de Imagens: Uma } \\
\text { Proposta de Educação } \\
\text { Ambiental }\end{array}$ & $\begin{array}{l}\text { Dos Santos \& Silva, } \\
2007\end{array}$ & $\begin{array}{l}\text { Observação dos pontos } \\
\text { potenciais de } \\
\text { contaminação }\end{array}$ \\
\hline $\begin{array}{ll}\text { Revista } & \text { Águas } \\
\text { Subterrâneas } & \end{array}$ & $\begin{array}{l}\text { Impacto do } \\
\text { Necrochorume nas } \\
\text { águas subterrâneas do } \\
\text { Cemitério de Santa Inês, } \\
\text { Vila Velha-ES, Brasil }\end{array}$ & $\begin{array}{l}\text { Terra, } \quad \text { Santos \& } \\
\text { Freire, } 2008\end{array}$ & $\begin{array}{l}\text { Amostras de água } \\
\text { subterrânea em poços } \\
\text { de monitoramento }\end{array}$ \\
\hline $\begin{array}{ll}\text { Revista } & \text { Águas } \\
\text { Subterrâneas } & \end{array}$ & $\begin{array}{l}\text { Avaliação da qualidade } \\
\text { da água do aquífero livre } \\
\text { na região do Cemitério } \\
\text { Bom Jesus dos Aflitos, } \\
\text { Russas-CE, Brasil }\end{array}$ & Cunha et al., 2008 & $\begin{array}{lr}\text { Análises } & \text { físico- } \\
\text { químicas } & \mathrm{e} \\
\text { microbiológica da água }\end{array}$ \\
\hline $\begin{array}{l}\text { Revista Brasileira de } \\
\text { Ciências Ambientais }\end{array}$ & $\begin{array}{l}\text { Cemitérios como áreas } \\
\text { potencialmente } \\
\text { contaminadas }\end{array}$ & Silva \& Filho, 2008 & $\begin{array}{lll}\begin{array}{l}\text { Relação } \\
\text { cemitérios } \\
\text { ambiente }\end{array} & \text { e } & \begin{array}{l}\text { entre } \\
\text { meio }\end{array} \\
\end{array}$ \\
\hline $\begin{array}{ll}\text { Revista } & \text { Águas } \\
\text { Subterrâneas } & \end{array}$ & $\begin{array}{lr}\text { Impactos causados por } \\
\text { Necrochorume } \\
\text { Cemitérios: } \\
\text { Ambiente e } \\
\text { Pública }\end{array}$ & Carneiro, 2009 & Revisão de Literatura \\
\hline $\begin{array}{l}\text { Engenharia Sanitária e } \\
\text { Ambiental }\end{array}$ & $\begin{array}{l}\text { O emprego de métodos } \\
\text { geofísicos na fase de } \\
\text { investigação } \\
\text { confirmatória } \\
\text { cemitérios } \\
\text { contaminados }\end{array}$ & Silva \& Filho, 2009 & $\begin{array}{l}\text { Eletrorresistividade } \\
\text { por meio das técnicas } \\
\text { da sondagem elétrica } \\
\text { vertical e imageamento } \\
\text { elétrico }\end{array}$ \\
\hline $\begin{array}{l}\text { Revista Brasileira de } \\
\text { Geografia }\end{array}$ & $\begin{array}{l}\text { Emprego do método da } \\
\text { eletrorresistividade no } \\
\text { estudo da contaminação } \\
\text { subterrânea do cemitério } \\
\text { municipal de Vila } \\
\text { Rezende, Piracicaba - } \\
\text { SP }\end{array}$ & $\begin{array}{l}\text { Silva, } \quad \text { Filho } \\
\text { Moreira, } 2009\end{array}$ & Eletrorresistividade \\
\hline $\begin{array}{ll}\text { Revista } & \text { Águas } \\
\text { Subterrâneas } & \end{array}$ & $\begin{array}{lr}\text { Influência } & \text { dos } \\
\text { cemitérios } & \text { na } \\
\text { contaminação da água } \\
\text { subterrânea em cidade } \\
\text { do sul do Brasil }\end{array}$ & Kemerich et al., 2010 & $\begin{array}{l}\text { "GOD" (G - } \\
\text { groundwater hydraulic } \\
\text { confinement; O - } \\
\text { overlaying strata; D - } \\
\text { depth to groundwater } \\
\text { table) }\end{array}$ \\
\hline $\begin{array}{l}\text { Cadernos de Educação, } \\
\text { Tecnologia e Sociedade }\end{array}$ & $\begin{array}{l}\text { Avaliação preliminar do } \\
\text { cemitério de Itaquera, } \\
\text { segundo a Resolução } \\
\text { CONAMA 335/2003, } \\
\text { Município de São Paulo }\end{array}$ & $\begin{array}{l}\text { Da Silva, Suguio \& } \\
\text { Pacheco, 2011 }\end{array}$ & $\begin{array}{l}\text { Entrevista, coleta e } \\
\text { análise de amostras, } \\
\text { levantamento } \\
\text { topográfico }\end{array}$ \\
\hline $\begin{array}{l}\text { Revista } \\
\text { Subterrâneas }\end{array}$ & $\begin{array}{l}\text { Avaliação físico- } \\
\text { química } \\
\text { microbiológica das } \\
\text { águas subterrâneas no } \\
\text { entorno do Cemitério do } \\
\text { bairro do aeroporto, } \\
\text { núcleo cidade nova, } \\
\text { cidade de Marabá, } \\
\text { Sudeste do Estado do } \\
\text { Pará }\end{array}$ & $\begin{array}{l}\text { Dos Santos \& Leal, } \\
2011\end{array}$ & $\begin{array}{l}\text { Análises físico- } \\
\text { químicas e } \\
\text { bacteriológicas de água } \\
\text { de poços próximas ao } \\
\text { cemitério }\end{array}$ \\
\hline
\end{tabular}




\begin{tabular}{|c|c|c|c|}
\hline $\begin{array}{l}\text { Revista } \\
\text { Subterrâneas }\end{array}$ & $\begin{array}{lr}\text { Contaminação } & \text { de } \\
\text { aquífero freático } & \text { por } \\
\text { Necrochorume } & \text { em } \\
\text { Bonito-MS } & \\
\end{array}$ & Lastoria et al., 2012 & $\begin{array}{l}\text { Georreferenciamento } \\
\text { de poços, medidas de } \\
\text { nível d'água e análise } \\
\text { microbiológica }\end{array}$ \\
\hline $\begin{array}{ll}\text { Revista } & \text { Águas } \\
\text { Subterrâneas } & \end{array}$ & $\begin{array}{lr}\text { Avaliação do risco de } \\
\text { contaminação da água } \\
\text { subterrânea } & \text { por } \\
\text { Necrochorume } & \text { no } \\
\text { cemitério municipal de } \\
\text { Sinop - MT }\end{array}$ & Lussi et al., 2012 & $\begin{array}{l}\text { Condutividade } \\
\text { hidráulica e teste de } \\
\text { permeabilidade }\end{array}$ \\
\hline $\begin{array}{l}\text { Revista Ambiente \& } \\
\text { Água }\end{array}$ & $\begin{array}{l}\text { Valores anômalos de } \\
\text { metais pesados no solo } \\
\text { do cemitério }\end{array}$ & Kemerich et al., 2012 & $\begin{array}{lr}\text { Análise } & \text { de } \\
\text { concentrações } & \text { de } \\
\text { metais pesados no solo }\end{array}$ \\
\hline Ciência e Natura & $\begin{array}{l}\text { Áreas ocupadas por } \\
\text { cemitérios e seus } \\
\text { impactos na qualidade } \\
\text { da água na cidade de } \\
\text { Santa Maria - RS, Brasil }\end{array}$ & Kemerich et al., 2012 & $\begin{array}{lr}\text { Análise } & \text { de } \\
\text { vulnerabilidade das } \\
\text { águas subterrâneas }\end{array}$ \\
\hline Agro@mbiente on-line & $\begin{array}{l}\text { Análise de impacto } \\
\text { ambiental e } \\
\text { identificação } \\
\text { implantação e operação } \\
\text { vertical de cemitério = } \\
\text { Análise e identificação } \\
\text { dos impactos ambientais } \\
\text { da implantação e } \\
\text { operação de cemitério } \\
\text { vertical }\end{array}$ & Albertin et al., 2013 & $\begin{array}{l}\text { Análise e classificação } \\
\text { de impactos }\end{array}$ \\
\hline Holos & $\begin{array}{l}\text { Teores de metais } \\
\text { pesados e caracterização } \\
\text { mineralógica dos solos } \\
\text { do Cemitério municipal } \\
\text { do Boqueirão, Curitiba - } \\
\text { PR, Brasil }\end{array}$ & Barros et al., 2013 & $\begin{array}{l}\text { Investigação } \\
\text { mineralógica e metais } \\
\text { pesados }\end{array}$ \\
\hline $\begin{array}{l}\text { Amazon's Research and } \\
\text { Environmental Law }\end{array}$ & 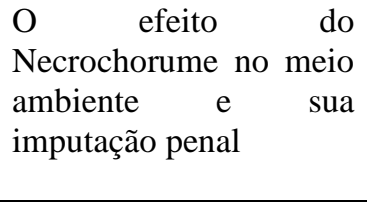 & Fernandes, 2014 & $\begin{array}{l}\text { Consequências } \\
\text { relativas } \\
\text { contaminação sem a } \\
\text { atendimento as normas } \\
\text { do CONAMA }\end{array}$ \\
\hline Ciência e Natura & $\begin{array}{lr}\text { Mapeamento } & \text { da } \\
\text { vulnerabilidade das } \\
\text { águas subterrâneas e uso } \\
\text { do solo na área urbana } \\
\text { do município de Nova } \\
\text { Palma - RS } \\
\end{array}$ & Carlos, 2014 & 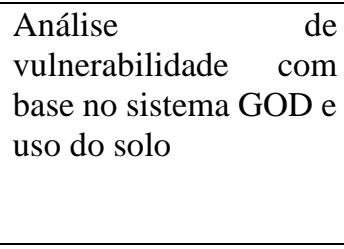 \\
\hline $\begin{array}{l}\text { Revista Eletrônica de } \\
\text { Gestão e Tecnologias } \\
\text { Ambientais }\end{array}$ & $\begin{array}{lr}\text { Qualidade da água } \\
\text { subterrânea } & \mathrm{e} \\
\text { Necrochorume } & \text { no } \\
\text { entorno do Cemitério do } \\
\text { Campo Santo em } \\
\text { Salvador - BA } \\
\end{array}$ & Dos Santos et al., 2015 & $\begin{array}{l}\text { Avaliação da qualidade } \\
\text { da água subterrânea de } \\
\text { poços rasos e cisternas }\end{array}$ \\
\hline $\begin{array}{l}\text { Revista da Universidade } \\
\text { Vale do Rio Verde }\end{array}$ & $\begin{array}{l}\text { Cemitérios horizontais e } \\
\text { verticais: } \\
\text { Peculiaridades, } \\
\text { impactos ambientais e } \\
\text { melhores práticas }\end{array}$ & Ferrari et al., 2015 & $\begin{array}{l}\text { Estudos bibliográficos, } \\
\text { levantamento da } \\
\text { legislação vigente, } \\
\text { visitas e entrevistas }\end{array}$ \\
\hline $\begin{array}{l}\text { Revista } \\
\text { Subterrâneas }\end{array}$ & $\begin{array}{l}\text { Métodos geoelétricos } \\
\text { aplicados ao diagnóstico } \\
\text { ambiental subsuperficial } \\
\text { do Cemitério municipal } \\
\text { de Rio Claro - SP }\end{array}$ & Xavier, 2015 & $\begin{array}{l}\text { Investigação } \\
\text { qualitativamente do } \\
\text { meio físico } \\
\text { subsuperficial }\end{array}$ \\
\hline
\end{tabular}




\begin{tabular}{|c|c|c|c|}
\hline $\begin{array}{l}\text { Revista Águas } \\
\text { Subterrâneas }\end{array}$ & $\begin{array}{c}\text { Análise do } \\
\text { abastecimento de água } \\
\text { do entorno dos } \\
\text { cemitérios São José e } \\
\text { São Francisco, } \\
\text { Castanhal - PA }\end{array}$ & Da Silva et al., 2015 & Informações \\
\hline Ciência e Natura & $\begin{array}{l}\text { Mapeamento ambiental } \\
\text { de áreas vulneráveis à } \\
\text { contaminação no } \\
\text { aquífero guarani no } \\
\text { município de Faxinal do } \\
\text { Saturno - RS, Brasil }\end{array}$ & Fabiano, 2015 & $\begin{array}{l}\text { Levantamento de áreas } \\
\text { potencialmente } \\
\text { contaminantes }\end{array}$ \\
\hline $\begin{array}{l}\text { Atas de Saúde } \\
\text { Ambiental }\end{array}$ & $\begin{array}{l}\text { Tratamento do } \\
\text { Necrochorume em } \\
\text { Cemitérios }\end{array}$ & Francisco et al., 2017 & Revisão \\
\hline $\begin{array}{l}\text { Anuário do Instituo de } \\
\text { Geociências }\end{array}$ & $\begin{array}{c}\text { Vulnerabilidade do } \\
\text { aquífero nas } \\
\text { proximidades do } \\
\text { Cemitério municipal de } \\
\text { Caçapava do Sul - RS, } \\
\text { Brasil }\end{array}$ & E Silva et al., 2017 & $\begin{array}{c}\text { GOD, correspondente } \\
\text { a G - groundwater } \\
\text { hydraulic confinement; } \\
\text { O - overlaying strata; } \\
\text { D - depth to } \\
\text { groundwater table }\end{array}$ \\
\hline $\begin{array}{l}\text { Urbe. Revista Brasileira } \\
\text { de Gestão Urbana }\end{array}$ & $\begin{array}{c}\text { Dano ambiental e } \\
\text { ameaça à saúde pública } \\
\text { por cemitérios: Uma } \\
\text { proposta de cemitério } \\
\text { ideal diante da crescente } \\
\text { expansão urbana }\end{array}$ & Neckel et al., 2017 & $\begin{array}{c}\text { Avaliar os níveis de } \\
\text { contaminação físico- } \\
\text { química e } \\
\text { microbiológica }\end{array}$ \\
\hline $\begin{array}{c}\text { Engenharia Sanitária e } \\
\text { Ambiental }\end{array}$ & $\begin{array}{c}\text { Emprego da sondagem } \\
\text { elétrica vertical } \\
\text { integrada às análises } \\
\text { químicas e } \\
\text { microbiológicas no } \\
\text { diagnóstico preliminar } \\
\text { da contaminação do } \\
\text { solo e da água } \\
\text { subterrânea no } \\
\text { cemitério municipal da } \\
\text { cidade de Rio Claro - } \\
\text { SP }\end{array}$ & Xavier et al., 2018 & $\begin{array}{l}\text { Investigar eventuais } \\
\text { alterações no meio } \\
\text { físico subsuperficial }\end{array}$ \\
\hline $\begin{array}{l}\text { Atas de Saúde } \\
\text { Ambiental }\end{array}$ & $\begin{array}{c}\text { Impactos ambiental } \\
\text { negativos causados por } \\
\text { necrópoles } \\
\end{array}$ & Santos, 2018 & Revisão \\
\hline $\begin{array}{l}\text { Revista Águas } \\
\text { Subterrâneas }\end{array}$ & $\begin{array}{c}\text { Influência do } \\
\text { comprimento da } \\
\text { frequência na } \\
\text { condutividade elétrica e } \\
\text { ph no cemitério }\end{array}$ & Rosa \& Ucker, 2019 & $\begin{array}{l}\text { Avaliar o nível do } \\
\text { lençol freático na } \\
\text { condutividade elétrica } \\
\text { e no pH }\end{array}$ \\
\hline $\begin{array}{l}\text { Revista Águas } \\
\text { Subterrâneas }\end{array}$ & $\begin{array}{c}\text { Caracterização } \\
\text { hidrogeológica de áreas } \\
\text { de cemitérios - Estudo } \\
\text { de caso }\end{array}$ & $\begin{array}{l}\text { Cauduro, Müller \& } \\
\text { Cavaler, } 2019\end{array}$ & $\begin{array}{l}\text { Caracterização de } \\
\text { solos }\end{array}$ \\
\hline
\end{tabular}

Fonte: Autores (2020) 
$\mathrm{O}$ parâmetro $\mathrm{O}$ será baixo quando a zona não saturada for composta de materiais impermeáveis ou consolidados (por exemplo, argilas, granitos relativamente frescos) e alto quando esse horizonte for feito de sedimentos permeáveis ou soltos (por exemplo, areias limpas, cascalhos, pedras calcárias cársicas) (FRAGA et al., 2013). A pesquisa na literatura mostra que os autores que aplicam o modelo GOD são relativamente recentes.

Para Braga (2016), dos métodos geofísicos existentes no mundo, os mais usados são os geoelétricos com todas suas diversas modalidades, seja para fins acadêmicos até atender solicitações de interesse da população, incluindo quase todas as áreas das Geociências. Dentro do grupo de métodos geoelétricos os mais destacados são: eletrorresistividade, polbarização induzida e o potencial espontâneo.

De acordo com Braga (2007), o método da eletrorrestividade pertence ao grupo dos métodos geoelétricos. Seu princípio é baseado na determinação da resistividade elétrica de diferentes materiais existentes no meio rochoso. $\mathrm{O}$ parâmetro físico de resistividade elétrica é um dos atributos fundamentais na maioria dos materiais geológicos, o qual reflete algumas características que determinam seus estados em termos de fraturamento e alteração principalmente, além de identificá-los conforme sua litologia, evitando com isso as escavações.

$\mathrm{Na}$ bibliografia, alguns trabalhos de análises de solos em áreas de cemitérios podem ser citados, como o de Charzynski, Bednarek e Zołnowska (2010), que correlacionou parâmetros químicos e físicos do solo do cemitério de Toruń, na Polônia, com solos fora da área contaminada. Identificaram grandes diferenças na estrutura, textura e composição química entre ambos; e o de Jonker \& Olivier (2012), que estudaram o cemitério de Zandfontein, em Tshwane, na África do Sul, e analisaram os solos do cemitério onde foram sepultados cerca de 60 mil caixões. Constataram excesso de metais pesados, de origem de práticas funerárias, e concluíram que os solos nas zonas com as cargas mais altas de sepultamentos eram mais contaminados do que nas partes menos utilizadas do cemitério e fora da área.

Quanto à distribuição dos artigos por ano, segundo o gráfico 1 , verifica-se o maior número de artigos no ano de 2015.

Gráfico 1. Número de publicações por ano até março de 2020.

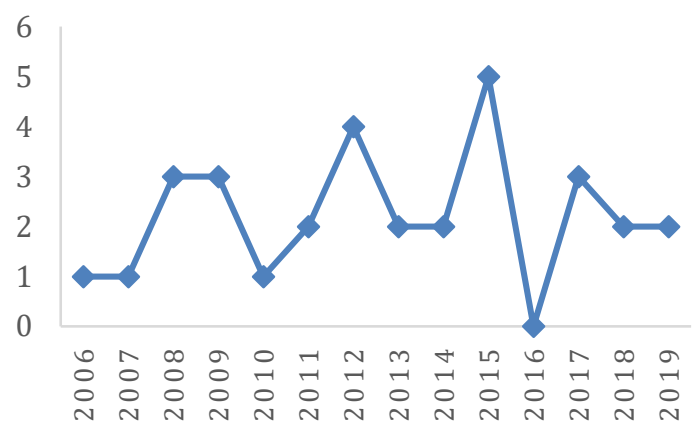

Fonte: Autores (2020)

A Organização das Nações Unidas (ONU) decretou o ano de 2015 como o ano Internacional dos Solos, esse pode ter sido um dos fatores que influenciou e resultou em um maior número de pesquisas relacionados a poluição e contaminação dos solos e águas subterrâneas por meio de cemitérios no mesmo ano, já que o solo é um agente protetor que funciona como filtro e mantem a qualidade das águas subterrâneas.

Entre as publicações, a maior parte dos trabalhos a são de revistas de Categoria B, conforme se observa no gráfico 2. Com relação aos autores, em alguns casos foi possível encontrar que um mesmo autor publicou mais de 1 artigo sobre a temática. 
Gráfico 2. Distribuição dos trabalhos por ano de publicação por categoria qualis da revista.

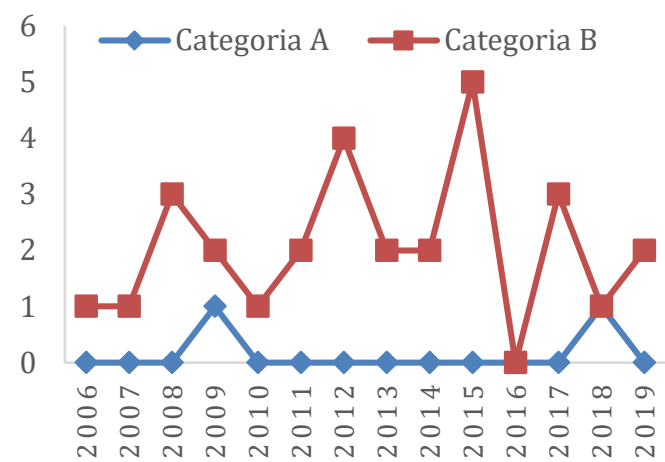

Fonte: Autores (2020)

A categoria B2 se destaca com 17 publicações seguido da categoria B1 com 5 . As demais categorias foram, B4 com 3, B3 com 2, B5 com 2 e A2 com 2 publicações.

A saber, a categoria A1 é a mais elevada de todas, seguida de A2, B1, B2, B3, B4, B5 e C, com peso zero, segundo as Classificações de 2010-2012 e 2013-2016. Na classificação de 2017-2020, a classificação será nos seguintes níveis: A1- mais elevado, A2, A3, A4, B1, B2, B3, B4, C - peso zero (CAPES, 2016).

Em relação a distribuição dos trabalhos quanto a localização das pesquisas, os estados que mais se destacaram foi São Paulo e Rio Grande do Sul, como podemos observar no gráfico 3.

Gráfico 3. Localidades estudadas nas pesquisas, considerando-se as universidades vinculadas na época da publicação dos artigos até março de 2020.



Fonte: Autores (2020)
Observa-se que a região Sudeste e Sul são as que mais investigaram a respeito da gestão de cemitérios. A escassez de estudos relacionados no Nordeste tem que ser alertada, pois, nas regiões áridas e semiáridas do mundo, os recursos hídricos são limitados e estão sob pressão devido à poluição, crescimento populacional, aumento do uso per capita de água e irrigação. A gestão dos recursos hídricos, especialmente águas subterrâneas, tornou-se uma questão cada vez mais premente nessas áreas (GHAZAVI et al., 2010).

Nessas regiões, as águas subterrâneas são um recurso valioso. Isto é a fonte de água local vital para a indústria, a agricultura e também como animais selvagens. As águas subterrâneas também são a principal fonte de água potável na área árida e semiárida e, portanto, sua avaliação de vulnerabilidades em áreas delineadas mais suscetível à contaminação é muito importante (IGHBAL et al., 2014).

Apesar de não encontrar trabalhos relacionados a temática no estado do Paraná, a cidade de Curitiba possui um Regulamento sobre Licenciamento de Cemitérios no Município de Curitiba, seus requisitos e condições técnicas, no que tange à conservação do ambiente, em particular do solo e águas subterrâneos (CURITIBA, 2011).

Autores como Jonker \& Olivier (2012), Charzynski, Bednarek e Zołnowska (2010), discorreram sobre a contaminação subsuperficial em áreas de cemitério os últimos anos, porém, os impactos causados aos solos por tais compostos não têm sido muito explorados.

\subsection{Sugestões para pesquisas futuras}

Para que haja uma redução nesses danos, são necessários cada vez mais intensificar a gestão ambiental para adequação desse ambiente, principalmente em pequenas localidades na qual dificilmente encontram-se órgãos vigentes para adequação desses empreendimentos já estabelecidos durante 
anos ou acompanhamento ambiental naquela localidade, para que possam buscar reverter, ou simplesmente controlar a contaminação do lençol freático e contaminações cruzadas por meio da agricultura.

Alguns mecanismos para controlar a proliferação do necrochorume são o uso dos filtros biológicos que são comuns nos cemitérios parque, porque sua eficiência depende da distância entre os jazidos; pastilhas que possui grande quantidade de bactérias consumidoras de matéria orgânica; mantas absorventes que são feitos a partir de um plástico muito resistente impermeável, que possui uma camada de celulose em pó no fundo, que em contato com o necrochorume se transforma um gel. Contudo, tais métodos são estratégias de aplicabilidade que irão controlar danos futuros, mas que não são efetivos para tratar ou combater contaminantes lá existentes, sendo possível observá-las mais para controle de roedores e proliferação de enfermidades naquela área.

\subsubsection{A fitorremediação como método de descontaminação}

A fitorremediação é o uso de plantas e comunidades microbianas associadas à rizosfera para degradar, isolar ou imobilizar contaminantes do solo e água. É uma técnica de custo relativamente baixo, vantagens estéticas e que não gera impactos adicionais (MARQUES et al., 2011).

Os mecanismos de descontaminação via fitorremediação entre eles: a fitoextração (absorção de contaminantes pelas raízes da planta), a fitoestabilização (contaminantes orgânicos e inorgânicos se incorporam na lignina da parede vegetal ou ao húmus do solo), a fitoestimulação (raízes em crescimento promovem a proliferação de microrganismos de degradação na rizosfera) e a fitodegradação (contaminantes orgânicos são degradados ou mineralizados dentro das células vegetais por enzimas específicas), se apresentam como uma estratégia de grande importância para adequação de futuros cemitérios, mas trata-se de um modelo bastante complexo e trabalhoso para sua aplicabilidade em cemitérios já estabelecidos, assim, acredita-se que com novos estudos pode-se encontrar novos mecanismos que se adequem também a antigos cemitérios em locais centrais das grandes e pequenas cidades sem os prévios cuidados ao meio ambiente. (FAVAS et al., 2014).

O sucesso no uso da fitorremediação para a descontaminação do solo contendo contaminantes orgânicos está relacionado à habilidade que o solo possui em absorvêlos e sequestrá-los, conforme a matriz do solo. (VASCONCELLOS et al., 2012). A interação entre plantas, poluente e solo é o primeiro passo para a realização eficaz da técnica de fitorremediação, porém vários estudos ainda terão que ser realizados para que esta técnica seja totalmente eficaz (CABRAL, 2016).

A técnica de fitorremediação caracteriza-se como uma tecnologia de remediação in situ para tratar solos e águas superficiais, águas subterrâneas e atmosfera contaminada com metais pesados, elementos radioativos ( $\mathrm{Sr}, \mathrm{Cs}, \mathrm{Pu}$ e U), solventes clorados, hidrocarbonetos de petróleo, BPCs, HPAs, inseticidas organofosforados e explosivos (AMADO e CHAVES FILHO, 2015).

A fitorremediação vem sendo estudada desde a década de 1990, principalmente nos Estados Unidos (EUA) e Europa. No Brasil, essa técnica vem ganhando espaço e inúmeras pesquisas vêm sendo desenvolvidas. A biodiversidade e condições climáticas brasileiras fazem dessa técnica uma alternativa promissora na remediação de áreas poluídas (LIMA, 2010).

Além disso, há plantas que conseguem retirar nutrientes do ambiente poluído e ainda acumular grandes quantidades de metais. Essas plantas são chamadas de hiperacumuladoras e com o auxílio de microrganismo absorvem vários compostos orgânicos e os degradam ou utilizam para diferentes funções ao realizar suas atividades 
metabólica (AMADO e CHAVES FILHO, 2015).

Para Barreto (2011), a diversidade de tipos de fitorremediação vem aumentando, haja vista os estudos desenvolvidos em parceria com a engenharia genética, pois esses estudos buscam integrar genes de outros organismos para melhorar as capacidades de fitorremediação em plantas.

Atividade extratora significativa do metal cobre foram descritos para a planta feijão-de-porco (Canavalia ensiformis), sorgo (Sorghum bicolor), milheto (Pennisetum glaucum) e crotalária (Crotalaria juncea) (ZANCHETA et al., 2011).

Já Mitton e colaboradores (2016) avaliaram o potencial de diferentes espécies vegetais (tomate, girassol, soja e alfafa) na remoção de endosulfan - pesticida organoclorado persistente e tóxico de uso proibido ou restrito em vários países em ensaios em casa de vegetação. No estudo, as plantas de girassol apresentaram alta produção de biomassa, maiores níveis de endolsufan nas raízes e folhas e consequentemente diminuição nos níveis de pesticida do solo.

Em estudo recente, Feitosa e Vital (2019), observaram o impacto da água residual de curtume no crescimento inicial de Atriplex nummularia Lindl. cultivada em luvissolo como estratégia de fitorremediação. De acordo com os autores, quanto maior a diluição da salmoura, menor a concentração dos sais nos solos, aumentando a altura, o diâmetro, o número de brotações, o número de raízes e o comprimento de raízes de $A$. nummularia; obtendo resultados significativos na remoção de sais do solo.

Além disso, a eficácia do processo de remoção de contaminantes em técnicas de remediação pode ser maximizada com acoplamento de tecnologias (RODRIGO et al., 2014). Cada tecnologia apresenta vantagens e desvantagens durante a aplicação para tratamento de solos contaminados.

Muitos estudos realizados comprovam que a fitorremediação é eficiente para tratar vários contaminantes diferentes, no entanto, a maioria das pesquisas, mesmo reconhecendo o potencial dessa técnica, considera que novos estudos precisam ser realizados, no intuito de melhor entender os mecanismos biológicos envolvidos no processo da fitorremediação e assim poder ampliar a sua aplicação a diferentes ambientes poluídos como cemitérios.

\subsubsection{Matriz de SWOT aplicada como ferramenta de estratégia ambiental}

A Análise SWOT é utilizada para auxiliar as organizações na identificação da sua direção estratégica, ou seja, conhecerem a si mesmas e ao seu entorno (ANDRADE e AMBONI, 2010).

Em sua dissertação de mestrado, Dutra (2014), desenvolve uma abordagem e comprova a eficiência da Análise SWOT em diversas aplicações. $O$ autor afirma que devido à característica interdisciplinar da Análise SWOT apresenta caráter interdisciplinar, desta forma, sendo possível sua adequação a diferentes tipos de estudo.

Dentre as ferramentas de Planejamento utilizadas, destaca-se a Matriz SWOT, que é uma sigla em inglês que representa: Forças (Strengths), Fraquezas (Weaknesses), Oportunidades (Opportunities) e Ameaças (Threats), fundamentada por Kenneth Andrews e Roland Christensen (NETO, 2011). Ela permite a visualização das variáveis internas e externas de uma organização, em uma visão do todo, possibilitando identificar problemas e suas medidas corretivas.

Essa análise consiste em uma ferramenta instrumental para direcionar ações a fim de equalizar a estratégia organizacional, permitindo que a comparação dos ambientes internos e externos seja feita de forma eficiente, possibilitando assim um melhor ajuste da organização no meio que está situada (SERRA, 2015).

Cruz et al. (2015) afirmam que nenhum método atenderá todos os quesitos durante a realização de uma análise, mas que 
esse fator depende principalmente da profundidade da análise, posição do negócio e das necessidades do tomador de decisão. A partir das análises realizadas com a SWOT, a organização pode perceber com clareza o que deve ser modificado, quais medidas devem ser tomadas e que estratégias devem ser adotadas para que suas metas e objetivos sejam atingidos (QUEIROZ et al., 2012).

Desta forma, é possível observar os cenários e estratégias da fitorremediação através da matriz SWOT (Tabela 2).

Tabela 2. Cenários e estratégias da fitorremediação identificados a partir da Matriz SWOT

\begin{tabular}{|c|c|c|}
\hline \multirow{4}{*}{ 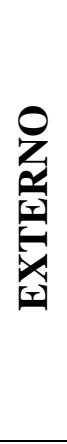 } & OPORTUNIDADES & AMEAÇAS \\
\hline & $\begin{array}{l}\text { Controle erosivo, } \\
\text { hídrico e eólico }\end{array}$ & $\begin{array}{l}\text { Distância dos } \\
\text { contaminantes }\end{array}$ \\
\hline & Não invasivo & $\begin{array}{c}\text { Tecnologia em } \\
\text { desenvolvimento }\end{array}$ \\
\hline & $\begin{array}{c}\text { Benefícios estéticos } \\
\text { da paisagem }\end{array}$ & Clima \\
\hline \multirow{5}{*}{ 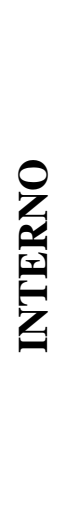 } & FORÇAS & FRAQUEZAS \\
\hline & Baixo custo & $\begin{array}{l}\text { Seleção de } \\
\text { plantas }\end{array}$ \\
\hline & Tratamento in situ & $\begin{array}{l}\text { Tempo de } \\
\text { remoçãa }\end{array}$ \\
\hline & Fácil controle & \\
\hline & $\begin{array}{c}\text { Redução de } \\
\text { transporte de } \\
\text { contaminantes no } \\
\text { solo }\end{array}$ & \\
\hline
\end{tabular}

Fonte: Autores (2020)

Observa-se, portanto, que tanto a Ameaça, quanto a Fraqueza da fitorremediação do solo está relacionada a barreiras naturais como tempo de remoção e clima local da área. Além disso, a ausência de estudos para o enquadramento da técnica para atuação nessas áreas se dá devido a seleção de plantas para tal finalidade.
É desejável que as plantas que apresentem potencial para fitorremediação possuam algumas características; entre elas está a capacidade de absorção, concentração e/ou metabolização e tolerância ao contaminante. Esses indicativos para seleção das plantas são fundamentais para que exista um tratamento e contenção do local contaminado.

Quanto às Forças e Oportunidades, verifica-se que na área, as plantas ajudariam no controle do processo erosivo, eólico e hídrico. Nesse último caso, evitariam o carregamento de contaminantes como necrochorume para a água e o solo e, por conseguinte, iriam reduzir a possibilidade de contaminação de lagos e rios, tratando o solo no local de contaminação, removendo, imobilizando ou tornando os contaminantes inofensivos ao ecossistema.

\section{Considerações finais}

As referências bibliográficas analisadas demonstraram o quanto a criação de um cemitério de forma imprópria causa danos ao meio ambiente e a população em geral, mostrando o quanto é importante a presença de um profissional adequado para manutenção dele, seja ele em funcionamento ou em fase de elaboração.

A região sul do país é a que mais tem investido em pesquisas e tecnologias nesses empreendimentos, enquanto que a região norte/nordeste ainda é um pouco escassa essa área de pesquisa.

Mesmo sabendo que o Brasil possui legislação que rege a gestão para a criação de novos cemitérios, mostra-se ainda a importância de manutenção de antigos cemitérios que foram empreendidos de sem um prévio estudo que culminou em danos ambientais desde seu estabelecimento.

Dessa forma, se faz necessário um estudo nesses locais, a fim da elaboração de uma gestão simples e efetiva, minimizando cada vez mais de a proliferação do 
necrochorume no lençol freático e demais poluidores ambientais.

Através da metodologia SWOT, foi possível identificar forças, fraquezas, ameaças e oportunidades aplicada junto a técnica de fitorremediação na gestão e remediação em áreas de cemitérios.

Contudo, o conhecimento desses fatores permite a adoção de medidas para otimização da gestão ambiental de cemitérios como um método de grande relevância que deve se tornar cada vez mais comum, onde a fitorremediação surge como uma estratégia que possa trazer ganhos ambientais significativos nessas localidades.

\section{Referências}

AMADO, S; CHAVES FILHO, J. T. Fitorremediação: uma alternativa sustentável para remedição de solos contaminados por metais pesados. Natureza on-line, v.13, n.4, p.158-164. 2015. Disponível em: http://www.naturezaonline.com.br/natureza/c onteudo/pdf/Amado\%20S, $\% 20$ Chaves $\% 20 \mathrm{Fi}$ lho\%20JT-corrigido.pdf. Acesso em: 20 de janeiro de 2020.

ANDRADE, R. O. B., \& AMBONI, N. Estratégia de gestão: processos e funções do administrador. Rio de Janeiro: Elsevier. 2010.

BARRETO, A. A seleção de macrófitas aquáticas com potencial para remoção de metais-traço em fitorremediação. 2011. 113f. Dissertação (Mestrado em Saneamento, Meio Ambiente e Recursos Hídricos) Instituto de Ciências Biológicas, Universidade Federal de Minas Gerais, Belo Horizonte, 2011. Disponível em: http://www.smarh.eng.ufmg.br/defesas/941M .PDF. Acesso em 11 de janeiro de 2020.

BRAGA, A. C. O. Geofisica aplicada: métodos geoelétricos em Hidrogeologia. São Paulo, 2016. 159 p.
BRAGA, A. C. O. Métodos Geoelétricos Aplicados nos estudos de Captação e Contaminação das Águas Subterrâneas. Instituto de Geociências e Ciências Exatas IGCE, Departamento de Geologia Aplicada DGA. UNESP. Rio Claro, p.79. 2007.

CABRAL, C. M., SANTOS, J. B. Grupo INOVAHERB: excelência em pesquisas sobre fitorremediação de ambientes com resíduos de herbicidas no Brasil. Revista Científica Vozes dos Vales, MG, n.9, p.1-11. 2016.

CHARZYNSKI, P., BEDNAREK, R., ZOŁNOWSKA, B. Characteristics of the soils of Torun cemeteries. In: WORLD CONGRESS OF SOIL SCIENCE, SOIL SOLUTIONS FOR A CHANGING WORLD, 19., 2010, Brisbane, Austrália. Anais... Brisbane. 2010.

COORDENAÇÃO DE APERFEIÇOAMENTO DE PESSOAL DE NÍVEL SUPERIOR (CAPES). Qualis Periódicos. Disponível em: https://sucupira.capes.gov.br/sucupira/public/ index.jsf. Acesso em: 17 de julho de 2020.

CRUZ, D. F., SAKAYA, A. Y., FERREIRA, M. G. G., FORCELLINI, F. A., ANJOS, S. J. G., ABREU, A. F., \& CAUCHICK MIGUEL, P. A. Inteligência competitiva em organizações de serviços: uma revisão sistemática da literatura. Revista Produção Online. v.15, n.1, p.50-77. 2015. http://dx.doi. org/10.14488/1676-1901.v15i1.1663.

CURITIBA. Secretaria Municipal de Meio Ambiente. Decreto Municipal $\mathbf{n}^{\circ} \mathbf{1 0 8 0}$, de 05 de julho de 2011. Aprova o regulamento sobre licenciamento ambiental de cemitérios e estabelece requisitos, condições técnicas, no que tange à proteção e conservação do ambiente, em particular do solo e das águas subterrâneas. Diário Oficial do Município, Poder Executivo, Curitiba, PR, 05/07/2011, 15p, 2011. 
CUTRIM, A. O. \& CAMPOS, J. E. G. Avaliação da vulnerabilidade e perigo à contaminação do aquíferos furnas na cidade de Rondonópolis (MT) com aplicação dos métodos GOD e POSH. Geociências. v.29, n.3, p.401- 4011. 2010.

DUTRA, D. V. A análise SWOT no Brand DNA Process: um estudo da ferramenta para aplicação em 13/14 Gestão estratégica em trabalhos em Branding. (Dissertação de mestrado). Curso de Design e Expressão Gráfica, Universidade Federal de Santa Catarina, Florianópolis. 2014.

FAVAS, P. J. C., PRATAS, JP., VARUN, M., D'SOUZA, R., PAUL, MS. Phytoremediation of Soils Contaminated with Metals and Metalloids at Mining Areas: Potential of Native Flora. In: Environmental Risk Assessment of Soil Contamination, Maria C. Hernandez Soriano, editors. InTech. p.485517. 2014.

FEITOSA, J. F. F., VITAL, A. F. M. Impacto da água residual de curtume no crescimento inicial de Atriplex nummularia Lindl. cultivada em luvissolo. Acta Biológica Catarinense. v.6, n.4, p. 61-72, 2019.

FIEDLER, S. et al. Graveyards - Special landfills. Science of the Total Environment, v. 419, p. 90-97, 2012.

FOSTER, S. S. D. Fundamental concepts in aquifer vulnerability, pollution risk and protection strategy. Vulnerability of soil and groundwater to pollutants. v.38, p.69-86. 1987.

FRAGA, C. M. et al. Exploratory assessment of groundwater vulnerability to pollution in the Sordo River Basin, Northeast of Portugal. Rem. Revista Escola de Minas. v.66, n.1. 2013. https://doi.org/10.1590/S037044672013000100007.
GHAZAVI, R., THOMAS, Z., HAMON, Y., MEROT, P. Soil water movement under a bottomland hedgerow during contrasting meteorological conditions. Hydrol Process. v.25, p.9-30. 2011.

GIL, A. C. Como elaborar projetos de pesquisa. Ed. Atlas, São Paulo. 2017.

GREENHALGH, T. How to read a paper: Papers that summarise other papers (systematic reviews and meta-analyses). Bmj, v.315, n.7109, p.672-675. 1997.

GUBA, E. G., \& LINCOLN, Y. S. Paradigmatic controversies, contradictions, and emerging confluences. The Sage handbook of qualitative research. p.191215. 2005.

IGHBAL, J., GORAI, A. K., KATPATAL, Y. B., PATHAK, G. Development of GIS-based fuzzy pattern recognition model (modified DRASTIC model) for groundwater vulnerability to pollution assessment. Int $\mathbf{J}$ Environ Sci Technol. 2014. doi:10.1007/s13762-014-0693-x.

JONKER， C.; OLIVIER， J. Mineral contamination from cemetery soils: case study of Zandfontein Cemetery, South Africa. International Journal of Environmental Research and Public Health, n. 9, p.511-520. 2012. DOI: 10.3390/ijerph9020511.

KEMERICH, P. D. C., BIANCHINI, D. C., FANK, J. C., BORBA, W. F., WEBER, D. P. \& UCKER, F. E. A questão ambiental envolvendo os cemitérios no Brasil. Revista Monografias Ambientais-REMOA, LPMA/UFSM, v.13, n.5, p.3777-3785. 2014.

KEMERICH, P. D. C., UCKER, F. E. \& BORBA, W. F. Cemitérios como fonte de contaminação ambiental. Scientific American Brasil. v.123, p.78-81. 2012. 
LIMA, A. M. Avaliação do potencial fitorremediador da mamona e girassol quanto à remoção de chumbo e tolueno em efluentes sintéticos. 2010. 110f. Tese (Doutorado em Engenharia Química) - Centro de Tecnologia, Universidade Federal do Rio Grande do Norte, Natal, 2010. Disponível em: http://www.repositorio.ufrn.br:8080/jspui/bit stream/123456789/15900/1/AnitaML_TESE. pdf.

MAIA, P. H. P. \& CRUZ, M. J. M. Um novo método para avaliar a vulnerabilidade de aquíferos. Braz. J. Aquat. Sci. Technol. v.15, n.2, p.29-40. 2011.

MARTINS, G., e THEÓPHILO, C. Metodologia da investigação científica para ciências sociais aplicadas. São Paulo: Atlas, 2007. 225p

MARQUES, M., AGUIAR, C. R. C., SILVA, J. J. L. S. Desafios técnicos e barreiras sociais, econômicas e regulatórias na fitorremediação de solos contaminados. Revista Brasileira de Ciência do Solo, Viçosa, MG. v.35, n.1, p.111, 2011.

MITTON, F. M., MARIANA GONZALEZ, J. O. S., MONSERRAT, E. M., KARINA MIGLIORANZA, S. B. Potential use of edible crops in the phytoremediation of endosulfan residues in soil. Chemosphere. v.148, p.30030. 2016.

NETO, E. R. Análise SWOT - Planejamento Estratégico para Análise de Implantação e Formação de Equipe de Manutenção em uma Empresa de Segmento Industrial. Faculdade Pitágoras - Núcleo de Pós Graduação. 2011.

RODRIGO, M. A., OTURAN, N., OTURAN, M. A. Electrochemically Assisted Remediation of Pesticides in Soils and water: A Review, Chem. Rev. v.114, p.8720-8745. 2014.
SANTOS, J. G. C., CALÍOPE, T. S. \& BARROS NETO, J. D. P. Sessão especial Fast Track SEMEAD: Tem ação nessa pesquisa? Um levantamento da pesquisa-ação como estratégia de pesquisa qualitativa. Revista de Gestão. v.24, n.4, p.336-347. 2017.

SERRA, P. V. Caixa de Ferramentas de Produção e Análise de Informação: Análise SWOT. Faculdade de Economia e Faculdade de Psicologia e de Ciências da Educação. Coimbra.Universidade de Coimbra, 2015.

VASCONCELLOS, M. C., PAGLIUSO, D., SOTOMAIOR, V. S. Fitorremediação: Uma proposta de descontaminação do solo. Estudos de Biologia, [s.l.]. Pontificia Universidade Católica do Paraná - PUCPR. v.34, n.421, p.261-267. 2012.

ZANCHETA, A. C. F., ABREU, C. A., ZAMBROSI, F. C. B., ERISMANN, N. M. \& LAGÔA, A. M. M. A. Fitoextração de cobre por espécies de plantas cultivadas em solução nutritiva. Bragantia. v.70, p.737-744. 2011.

Figura 1. Descrição da figura (sempre quando houver devem ser inserida após citadas no texto). 